Aleksandra DEKAŃSKA-KIELAR

Uniwersytet Łódzki

\title{
UWARUNKOWANIA UPRAWIANIA WSPINACZKI NA SZTUCZNYCH ŚCIANKACH W WOJEWÓDZTWIE ŁÓDZKIM
}

\section{Wstęp}

Od pewnego czasu w Polsce zaobserwować można wzrost zainteresowania uprawianiem wspinaczki, definiowanej jako ,pokonywanie trudnego terenu górskiego z wykorzystaniem jego naturalnej rzeźby lub za pomocą sztucznych ułatwień, często $\mathrm{z}$ użyciem specjalistycznego sprzętu wspinaczkowego" (KIEŁKOWSKA 2003). Takie rozumienie wspinaczki, której uprawianie wymaga umiejętności posługiwania się specjalistycznym sprzętem i odpowiedniego przygotowania psychofizycznego pozwala zaklasyfikować ją jako formę turystyki kwalifikowanej (DURYDIWKA 2006, MERSKI, WARECKA, 2009, LIJEWSKI, MIKUŁOWSKI, WYRZYKOWSKI 2008).

Wzrastającej popularności wspinaczki towarzyszy rozwój infrastruktury wspinaczkowej $\mathrm{w}$ postaci sztucznych ścianek wspinaczkowych, stanowiących alternatywę dla walorów naturalnych. Wspinaczka na sztucznych panelach wspinaczkowych określana jest mianem wspinaczki halowej (KIEŁKOWSKA 2003). W tej formie rekreacji chętnie biorą udział zarówno doświadczeni wspinacze, jak i osoby początkujące. Ogromnym atutem sztucznych 
ścianek jest to, że umożliwiają uprawianie wspinaczki przez cały rok, również w sezonie zimowym.

Pierwsze próby korzystania ze sztucznych obiektów wspinaczkowych sięgają początków XX w. Za prekursora tego rodzaju wspinaczki uznaje się Amerykanina, Olivera Perrye'go Smitha, który wykorzystywał w celach treningowych podmurówkę swojego ranczo. W latach 60. minionego stulecia w Wielkiej Brytanii powstała pierwsza sztuczna ściana wspinaczkowa. Jej twórcą był Don Robinson, który przystosował do potrzeb wspinaczy część korytarza w Uniwersytecie $\mathrm{w}$ Leeds. W ścianach wykuto dziury i wmurowano naturalne kamienie. Milowym krokiem dla rozwoju sztucznych paneli było opracowanie w 1983 r. przez Francois Savignego technologii produkcji sztucznych chwytów, będących mieszanką żywicy epoksydowej i piasku szklarskiego. Od tego czasu budowanie sztucznych ścian stało się szybko rozwijającym i intratnym interesem (KUŚKA, SAS-NOWOSIELSKI 1998).

W Polsce pierwsza ścianka wspinaczkowa powstała w latach 80. XX w. Wykorzystano $\mathrm{w}$ tym celu 20-metrowy szyb nieczynnej windy w budynku należącym do Klubu Wysokogórskiego z Gliwic. Obecnie liczba ścianek szacowana jest na 450-500 obiektów i wciąż rośnie. Sztuczne panele instalowane są w szkołach, przedszkolach, parkach zabaw, centrach handlowych, miejskich ośrodkach sportu i rekreacji, klubach fitness itp.

Zainteresowanie uprawianiem wspinaczki można zauważyć również wśród mieszkańców województwa łódzkiego, o czym świadczy działalność trzech klubów wysokogórskich i funkcjonowanie sztucznych obiektów wspinaczkowych.

Przedstawione badania miały na celu przeanalizowanie stanu i wykorzystania istniejących w województwie łódzkim paneli wspinaczkowych, a także scharakteryzowanie osób z nich korzystających.

\section{Stan i wykorzystanie istniejących w województwie łódzkim obiektów wspinaczkowych}

W województwie łódzkim istnieje 13 sztucznych paneli wspinaczkowych ${ }^{1}$ (rys. 1). Poszczególne takie obiekty oddawano do użytku w latach 1992-2009.

\footnotetext{
${ }^{1}$ Stan z 01.12.2012 r. Podczas inwentaryzacji uwzględniono obiekty, z których korzystanie jest nadzorowane przez przeszkolony personel.
} 
Pierwszy panel powstał w Łodzi na potrzeby Akademickiego Klubu Górskiego. Okres obfitujący w największą liczbę oddanych do użytku ścianek wspinaczkowych przypada na lata 2005-2009. W połowie 2013 r. w Łodzi planowane jest oddanie kolejnego obiektu - Spot Bouldercafe.

Obecnie dwie spośród wszystkich ścianek (w Skierniewicach i Tuszynie) nie są udostępnione do użytku ze względu na brak aktualizacji atestu. Ścianka wspinaczkowa przy I LO w Pabianicach służy wyłącznie uczniom liceum, osoby postronne nie mają możliwości korzystania z niej. Większość ścianek wspinaczkowych jest umiejscowiona wewnątrz budynków, jedynie trzy są urządzone na zewnątrz - ścianki w Tuszynie, Szczercowie i na Górze Kamieńsk.

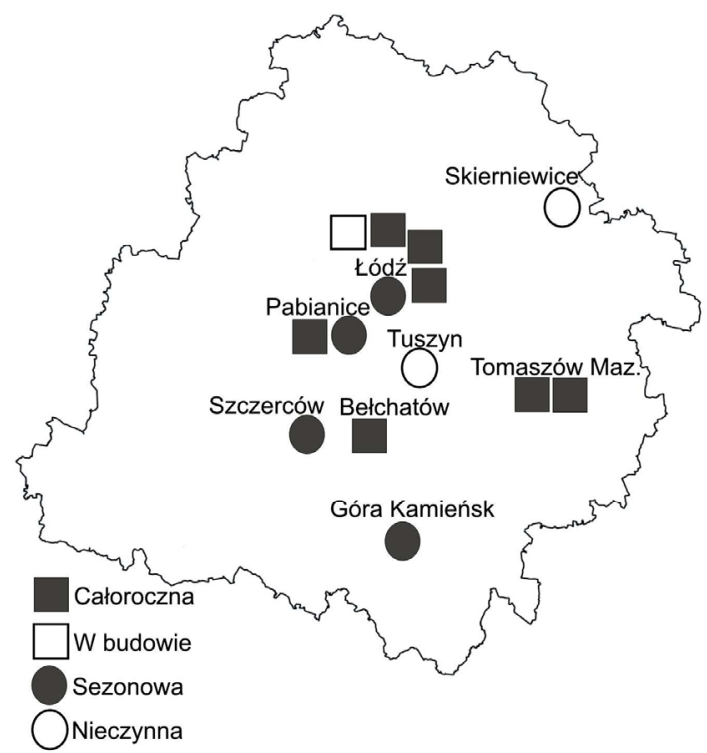

Rys. 1. Rozmieszczenie ścianek wspinaczkowych w województwie łódzkim (2011 r.)

Źródło: opracowanie własne na podstawie badań terenowych

Największym obiektem wspinaczkowym jest łódzka Stratosfera, zarówno pod względem wysokości, powierzchni użytkowej, jak i liczby stanowisk. Rozmiary pozostałych paneli są zbliżone (tab. 1). Z przeprowadzonej analizy wynika, że obiektami wspinaczkowymi zarządzają różne podmioty, m.in. urzędy gmin, szkoły, ośrodki sportu i rekreacji, domy kultury, organizacje społeczne, firmy, ale także osoby prywatne. 
Tabela 1. Charakterystyka paneli wspinaczkowych zlokalizowanych w województwie łódzkim w 2011 r.

\begin{tabular}{|c|c|c|c|c|c|}
\hline Miejscowość & $\begin{array}{c}\text { Nazwa/ } \\
\text { lokalizacja }\end{array}$ & $\begin{array}{c}\text { Wysokość } \\
\text { w m }\end{array}$ & $\begin{array}{c}\text { Powierzchnia } \\
\text { użytkowa } \\
\text { w m }{ }^{2}\end{array}$ & $\begin{array}{c}\text { Liczba } \\
\text { stanowisk }\end{array}$ & $\begin{array}{c}\text { Rodzaj } \\
\text { panelu/uwagi }\end{array}$ \\
\hline Łódź & Stratosfera & 10,0 & 500 & 40 & $\begin{array}{c}\text { panel } \\
\text { wewnętrzny }\end{array}$ \\
\hline Łódź & $\begin{array}{l}\text { Akademicki Klub } \\
\text { Górski }\end{array}$ & 6,6 & 200 & 6 & $\begin{array}{c}\text { panel } \\
\text { wewnętrzny }\end{array}$ \\
\hline Łódź & Intersport & 8,3 & 70 & 6 & $\begin{array}{c}\text { panel } \\
\text { wewnętrzny }\end{array}$ \\
\hline Łódź & $\begin{array}{l}\text { Wyższa Szkoła } \\
\text { Stosunków } \\
\text { Międzynarodowych }\end{array}$ & 8,0 & 70 & 6 & $\begin{array}{c}\text { panel } \\
\text { wewnętrzny }\end{array}$ \\
\hline Bełchatów & Hala Energia & 8,0 & 95 & 6 & $\begin{array}{c}\text { panel } \\
\text { wewnętrzny }\end{array}$ \\
\hline $\begin{array}{l}\text { Tomaszów } \\
\text { Mazowiecki }\end{array}$ & Miejski Dom Kultury & 7,0 & 70 & 4 & $\begin{array}{c}\text { panel } \\
\text { wewnętrzny }\end{array}$ \\
\hline $\begin{array}{l}\text { Tomaszów } \\
\text { Mazowiecki }\end{array}$ & $\begin{array}{l}\text { Ośrodek Szkolno- } \\
\text {-Wychowawczy }\end{array}$ & 6,0 & 60 & 9 & $\begin{array}{c}\text { panel } \\
\text { wewnętrzny }\end{array}$ \\
\hline Szczerców & $\begin{array}{l}\text { Kompleks Sportowo- } \\
\text {-Rekreacyjny }\end{array}$ & 7,5 & 65 & 5 & $\begin{array}{c}\text { panel } \\
\text { zewnętrzny }\end{array}$ \\
\hline $\begin{array}{l}\text { Góra } \\
\text { Kamieńsk }\end{array}$ & $\begin{array}{l}\text { Ośrodek Sportu } \\
\text { i Rekreacji „,Góra } \\
\text { Kamieńsk” }\end{array}$ & 7,5 & 75 & 8 & $\begin{array}{c}\text { panel } \\
\text { zewnętrzny }\end{array}$ \\
\hline Tuszyn & $\begin{array}{l}\text { Miejski Ośrodek } \\
\text { Kultury }\end{array}$ & 7,0 & 60 & 4 & $\begin{array}{c}\text { nieczynny - } \\
\text { brak atestu }\end{array}$ \\
\hline Skierniewice & $\begin{array}{l}\text { Ośrodek Sportu } \\
\text { i Rekreacji }\end{array}$ & 7,5 & 65 & 5 & $\begin{array}{c}\text { nieczynny - } \\
\text { brak atestu }\end{array}$ \\
\hline Pabianice & $\begin{array}{l}\text { I Liceum } \\
\text { Ogólnokształcące }\end{array}$ & 6,5 & 60 & 6 & $\begin{array}{c}\text { zamknięty } \\
\text { dla osób } \\
\text { postronnych }\end{array}$ \\
\hline Pabianice & Hala Powiatowa & 6,6 & 50 & 6 & $\begin{array}{c}\text { panel } \\
\text { wewnętrzny }\end{array}$ \\
\hline
\end{tabular}

Źródło: opracowanie własne na podstawie kart inwentaryzacyjnych.

Dla trzech ścianek - w Bełchatowie, Łodzi i Tomaszowie udało się pozyskać dane dotyczące liczby korzystających z nich osób w poszczególnych miesiącach 2011 r. (tab. 2). We wszystkich przypadkach można zauważyć znaczny spadek liczby użytkowników w miesiącach letnich. Intuicyjnie można wnioskować, że w tym czasie wyjeżdżają oni w teren wspinać się na skałach. 
Tabela 2. Użytkowanie sztucznych ścianek wspinaczkowych w województwie łódzkim według miesięcy w 2011 r.

\begin{tabular}{|c|c|c|c|c|c|c|c|c|c|c|c|c|}
\hline \multirow{2}{*}{$\begin{array}{c}\text { Lokaliza- } \\
\text { cja ścianki/ } \\
\text { nazwa }\end{array}$} & \multicolumn{12}{|c|}{ Miesiące } \\
\hline & I & II & III & IV & V & VI & VII & VIII & IX & $x$ & XI & XII \\
\hline $\begin{array}{l}\text { Łódź } \\
\text {-Stratosfera }\end{array}$ & 2482 & 2430 & 2998 & 1860 & 1348 & 1866 & 1565 & 1853 & 1935 & 2188 & 2331 & 2501 \\
\hline Bełchatów & 104 & 96 & 98 & 105 & 94 & 64 & 62 & 29 & 79 & 109 & 111 & 125 \\
\hline $\begin{array}{l}\text { Tomaszów } \\
\text { Mazowiecki }\end{array}$ & 87 & 79 & 73 & 81 & 68 & 60 & 52 & 48 & 72 & 79 & 82 & 81 \\
\hline
\end{tabular}

Źródło: opracowanie własne na podstawie kart inwentaryzacyjnych.

\section{Charakterystyka osób korzystających ze ścianek wspinaczkowych}

Badania wśród osób korzystających ze ścinek wspinaczkowych (które miały charakter pilotażowy) przeprowadzono metodą dostępnościową od 1 lipca do 10 września 2012 r. Odbyły się na terenie sztucznych obiektów wspinaczkowych w Bełchatowie, Łodzi, Tomaszowie Mazowieckim, Szczercowie i na Górze Kamieńsk. Badaniami objęto 201 użytkowników, wśród których przeważali mężczyźni, stanowiąc 69\% ogółu respondentów. Analiza struktury wieku ukazała przewagę osób w wieku 25-39 lat (65\%), na drugim miejscu znalazły się osoby w wieku 15-24 lat (32\%). Najsłabiej reprezentowana była grupa wiekowa 40-54 lata (3\%), a nie odnotowano w ogóle 55-latków i starszych. Tak małą liczbę użytkowników reprezentującą starsze przedziały wiekowe można tłumaczyć tym, że osoby młode chętniej niż ludzie starsi podejmują formy aktywności wymagające dobrej kondycji psychofizycznej.

Wśród ankietowanych dominowały osoby z wykształceniem wyższym (48\%) i średnim (35\%), a z wykształceniem podstawowym i gimnazjalnym stanowiły odpowiednio $2 \%$ i $13 \%$. Tylko $1 \%$ respondentów miało wykształcenie zawodowe (rys. 2). Powyższe dane mogą świadczyć o tym, że ze sztucznych paneli wspinaczkowych korzystają przede wszystkim osoby dobrze wykształcone.

Struktura wieku i wykształcenia znajduje odzwierciedlenie w statusie zawodowym. Osoby pracujące stanowiły $62 \%$ ogółu, status ucznia/studenta miało $37 \%$ badanych, a pozostali $(2 \%)$ to bezrobotni. Wśród respondentów nie było rencistów/emerytów. 
(\%)

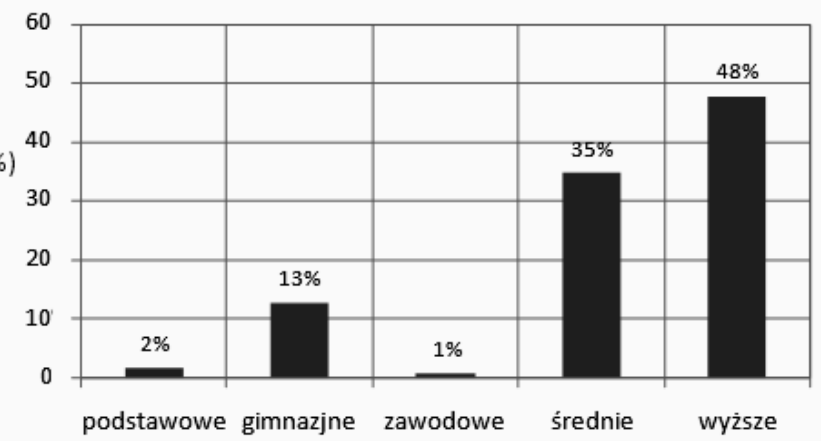

Rys. 2. Struktura wykształcenia respondentów $(n=201)$ korzystających z paneli wspinaczkowych województwa łódzkiego w $2011 \mathrm{r}$.

Źródło: opracowanie własne na podstawie badań ankietowych

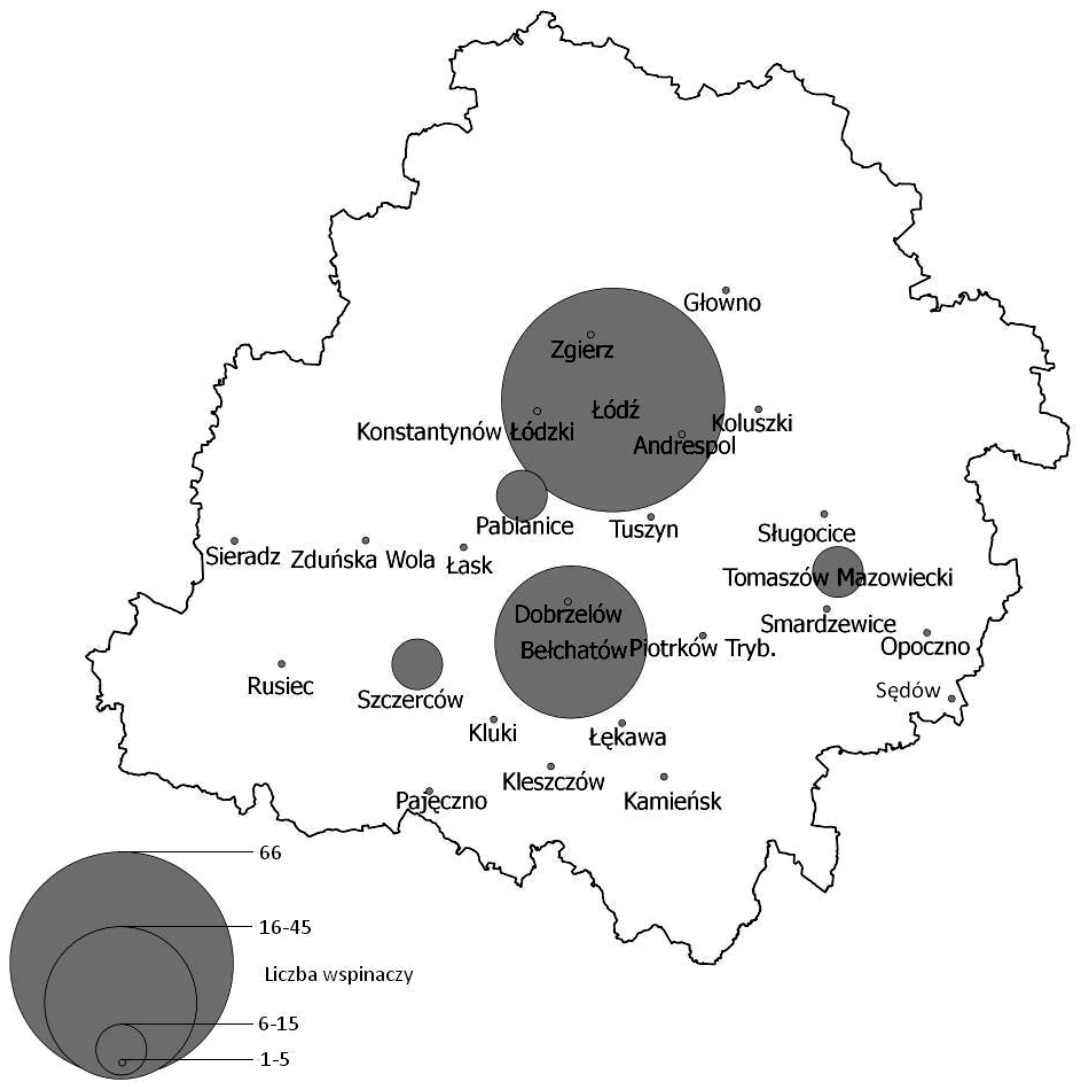

Rys. 3. Miejsce zamieszkania respondentów-wspinaczy - województwo łódzkie (2011 r.) Źródło: opracowanie własne na podstawie badań ankietowych 
Zdecydowana większość ankietowanych to mieszkańcy województwa łódzkiego. Pochodzili głównie z miejscowości, w których zlokalizowane są ścianki, bądź też znajdujących się w niewielkiej odległości od nich (rys. 3). Najwięcej osób było mieszkańcami Łodzi (42\%), następnie Bełchatowa (22\%) i Tomaszowa Mazowieckiego (11\%).

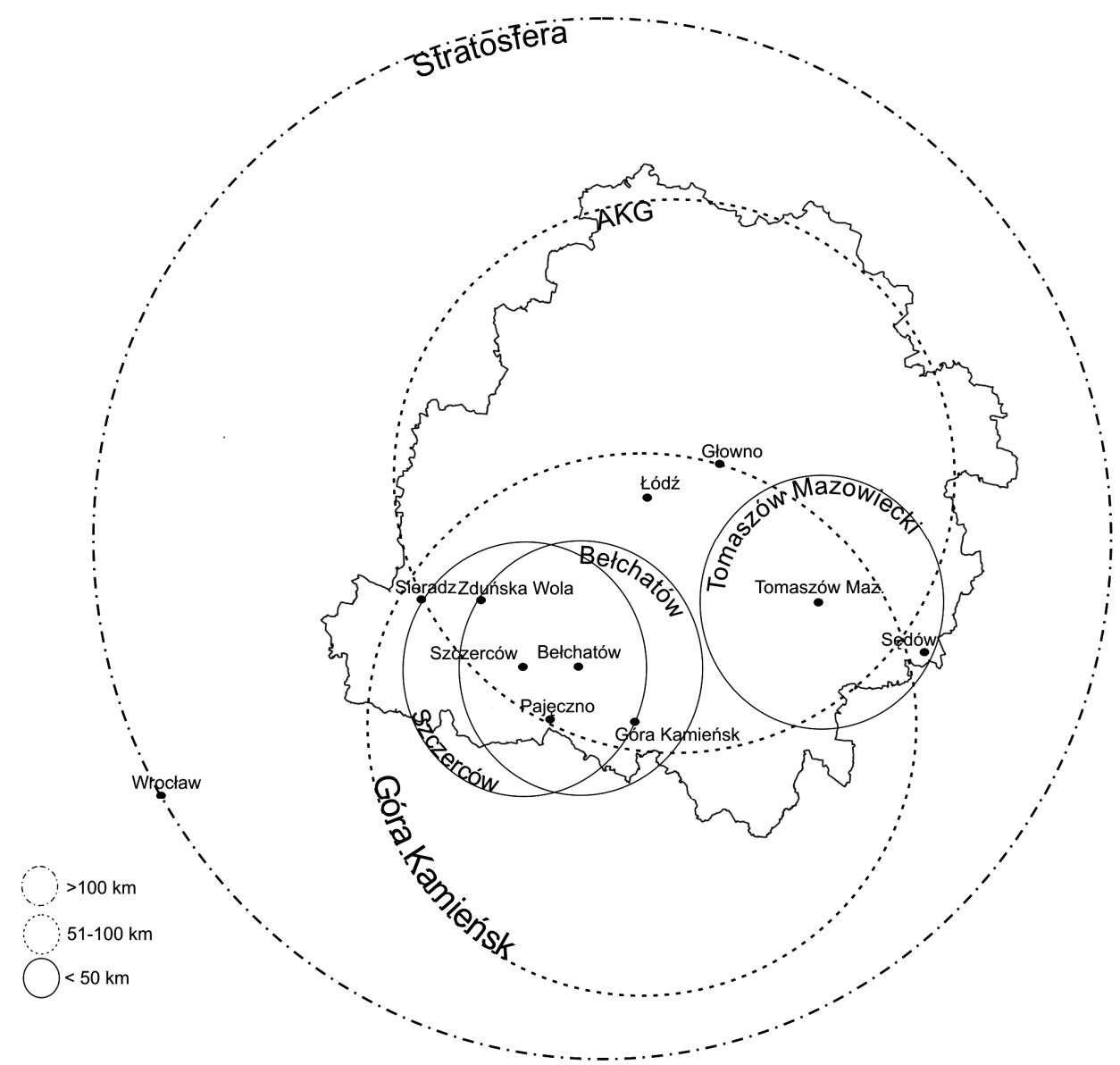

Rys. 4. Maksymalna odległość miejsca zamieszkania użytkowników paneli wspinaczkowych województwa łódzkiego w 2011 r.

Źródło: opracowanie własne na podstawie badań ankietowych

W przypadku obiektów wspinaczkowych w Bełchatowie, Szczercowie i Tomaszowie Mazowieckim odległość miejsca zamieszkania respondentów 
od nich wynosiła maksymalnie $50 \mathrm{~km}$. Dla ścianek AKG i na Górze Kamieńsk odległość wzrastała do $100 \mathrm{~km}$. Największym zasięgiem przestrzennym (powyżej $100 \mathrm{~km}$ ) odznaczyła się łódzka Stratosfera, gdzie wśród użytkowników tego panelu byli też mieszkańcy województw dolnośląskiego, mazowieckiego i opolskiego (rys. 4).

Jako główne powody korzystania ze ścianek wspinaczkowych respondenci wskazywali trening przed wyjazdem w teren na skały (42\%) i to, że lubią tę formę aktywności (36\%). Te odpowiedzi zaznaczały przede wszystkim osoby, które wspinają się od dłuższego czasu. Natomiast ankietowani, którzy po raz pierwszy korzystali ze sztucznych paneli odpowiadali, że „wspinają się dla towarzystwa” (11\%), chcą "sprawdzić własne możliwości” (6\%) lub też robią to „z ciekawości” (4\%) (rys. 5).

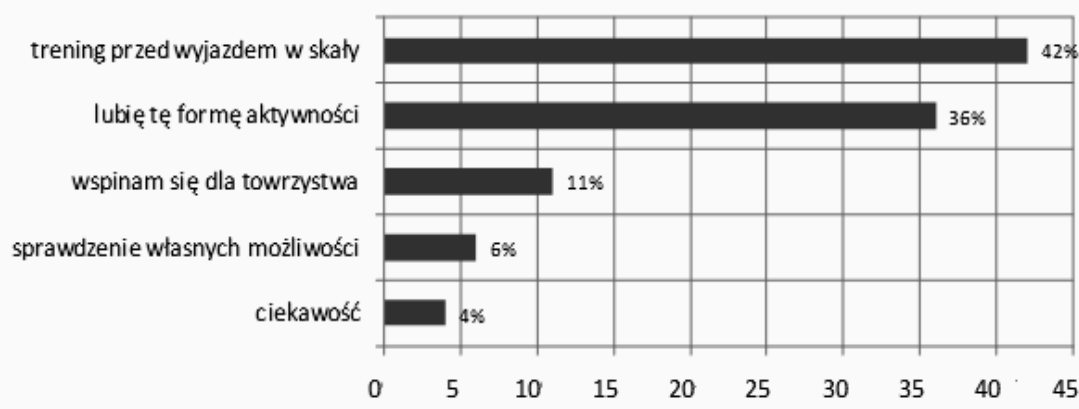

$(\%)$

Rys. 5. Motywy korzystania ze ścianek wspinaczkowych w województwie łódzkim w 2011 r. $(\mathrm{n}=201)$

Źródło: opracowanie własne na podstawie badań ankietowych

Większość ankietowanych korzystała ze sztucznych paneli wspinaczkowych po raz kolejny (82\%). Chęć ponownego korzystania $\mathrm{z}$ tego typu obiektów zadeklarowało $98 \%$ ogółu. Biorąc natomiast pod uwagę tylko osoby, które korzystały ze ścianki po raz pierwszy, taką deklarację złożyło 89\% $(n=36)$. Świadczy to o tym, że wspinaczka jest formą aktywności, do której chętnie się powraca, co dobrze rokuje powstawaniu nowych obiektów.

Ponad połowa respondentów korzysta ze ścianki wspinaczkowej raz w tygodniu i częściej (rys. 6). Tak dużą częstotliwość deklarowały osoby, dla których korzystanie $\mathrm{z}$ tego typu obiektów jest formą treningu przed wyjazdem $\mathrm{w}$ teren na skały. 


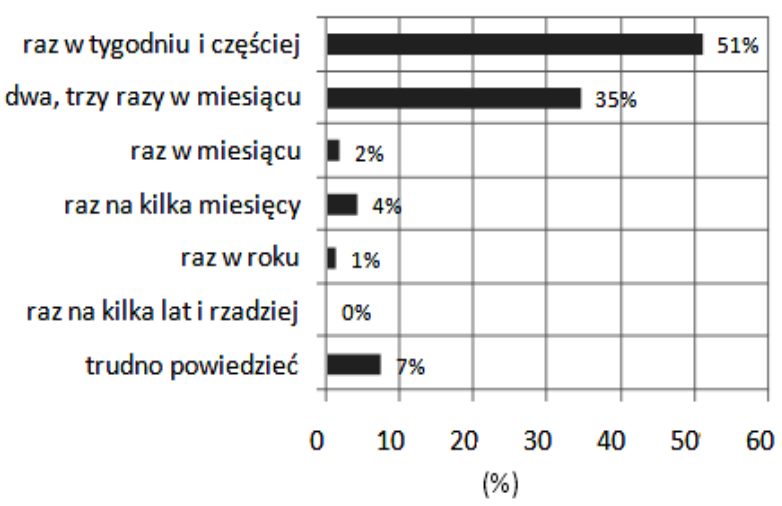

Rys. 6. Częstotliwość korzystania ze sztucznej ścianki wspinaczkowej

w województwie łódzkim w 2011 r. $(n=165)$

Źródło: opracowanie własne na podstawie badań ankietowych

Zdecydowanej większości ankietowanych podczas korzystania ze ścianek wspinaczkowych ktoś towarzyszył. Byli to znajomy(a)/znajomi (66\%), partner/partnerka (33\%) lub dziecko/dzieci (2\%). Jedynie 1\% respondentów wspina się sama (rys. 7). Wypływa z tego wniosek, że wspinaczka jest formą aktywności opartą $w$ dużej mierze na działaniu w zespole. Jest więc dyscyplina, która uczy współpracy z innymi, odpowiedzialności za partnera i służy budowaniu wzajemnych relacji.

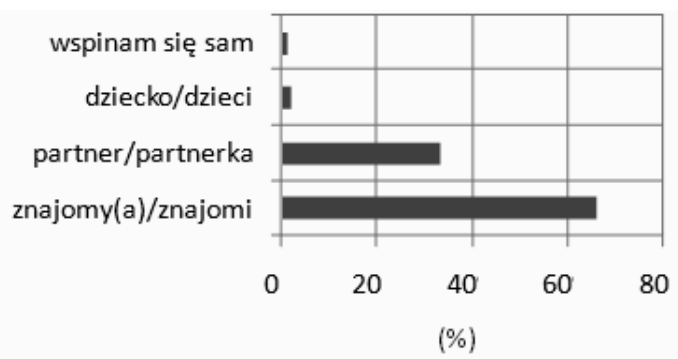

Rys. 7. Osoby towarzyszące respondentom podczas korzystania ze ścianki wspinaczkowej w województwie łódzkim w 2011 r.

Źródło: opracowanie własne na podstawie badań ankietowych

Ankietowanych poproszono o ocenę wybranych elementów/parametrów techniczno-użytkowych ścianek, z których korzystali (tab. 3). Najlepiej ocenionymi kategoriami w przypadku wszystkich paneli był poziom przy- 
gotowania personelu do ich obsługi i stan przyrządów asekuracyjnych. Oceny pozostałych parametrów dla poszczególnych obiektów wspinaczkowych były różne. Wielkość powierzchni użytkowej i różnorodność form wspinaczkowych zostały wysoko ocenione przez użytkowników łódzkiej Stratosfery i ścianki AKG. Nieco gorzej wypadły pod tym względem pozostałe panele: w Bełchatowie, Tomaszowie Mazowieckim, Szczercowie i na Górze Kamieńsk.

Biorąc pod uwagę średnią ocenę wyliczoną dla poszczególnych ścianek wspinaczkowych, na pierwsze miejsca wysuwają się Stratosfera $(4,04)$ i AKG $(4,02)$, następne $\mathrm{w}$ kolejności są panele $\mathrm{w}$ Bełchatowie $(3,14)$, Tomaszowie Mazowieckim $(3,06)$ i na Górze Kamieńsk $(3,02)$. Najgorzej oceniona przez respondentów została ścianka wspinaczkowa w Szczercowie (rys. 8).

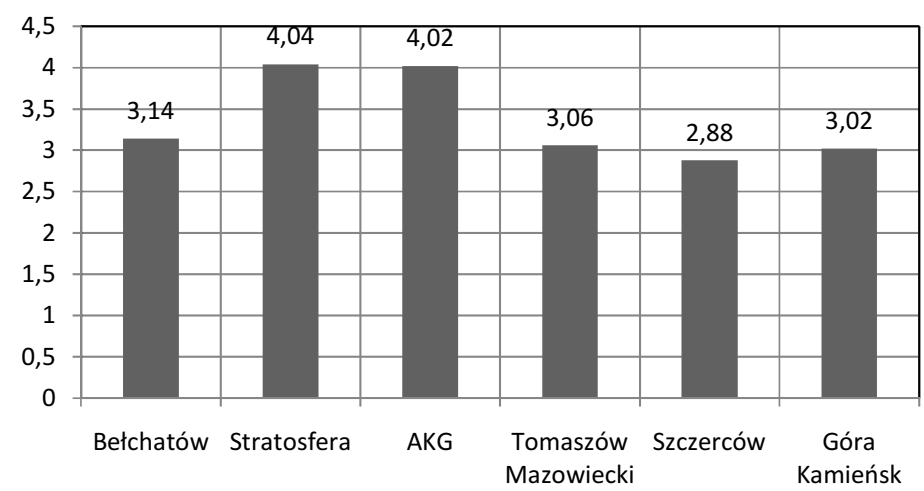

Rys. 8. Średnia ocena poszczególnych ścianek wspinaczkowych przez respondentów-wspinaczy w województwie łódzkim w 2011 r. Źródło: opracowanie własne na podstawie badań ankietowych

Respondentów zapytano też o to, czy korzystają z innych ścianek wspinaczkowych. Taką deklarację złożyło 57\% ankietowanych. Najczęściej wskazywanymi były ścianki w Łodzi: Stratosfera i ścianka AKG. Około 33\% ankietowanych korzysta ze ścianek $\mathrm{w}$ innych województwach - śląskim (Częstochowa, Katowice), mazowieckim (Warszawa), małopolskim (Kraków). Ponad połowa osób biorących udział w badaniu uprawia wspinaczkę na skałach w terenie (58\%). Najczęściej wskazywanymi rejonami były: Jura Krakowsko-Częstochowska i Sudety, a najrzadziej Góry Świętokrzyskie i Tatry. Można więc wnioskować, że użytkownicy ścianek wykazują dużą mobilność w uprawianiu wspinaczki. 
Blisko 1/4 respondentów zadeklarowała członkostwo w klubach wysokogórskich, padały dwie nazwy: Łódzki Klub Wysokogórski i Akademicki Klub Górski.

Dane uzyskane w trakcie badań pozwalają dokonać klasyfikacji istniejących obiektów wspinaczkowych:

1. Ze względu na długość funkcjonowania w ciągu roku:

a) całoroczne - panele wspinaczkowe są zamontowane wewnątrz budynków, co umożliwia wspinanie się przez cały rok, niezależnie od warunków pogodowych;

b) sezonowe - panele wspinaczkowe są umiejscowione na zewnątrz, ich użytkowanie jest ograniczone do miesięcy letnich, gdy warunki pogodowe są sprzyjające.

2. Ze względu na stopień dostępności dla użytkowników:

a) ogólnodostępne - korzystać może z nich każdy, kto tylko wyrazi taką chęć;

b) środowiskowe - przeznaczone tylko do użytku określonych grup, np. panele zamontowane w szkolnych salach gimnastycznych.

3. Ze względu na odległość miejsca zamieszkania użytkowników:

a) lokalne - odległość miejsca zamieszkania użytkowników od ścianki wspinaczkowej jest niewielka, jej zasięg przestrzenny ogranicza się do gmin znajdujących w najbliższym sąsiedztwie;

b) regionalne - zasięg przestrzenny wyznaczają granice województwa;

c) ponadregionalne - odległość miejsca zamieszkania użytkowników od ścianki wspinaczkowej jest znaczna, przekracza granice województwa.

\section{Podsumowanie i wnioski końcowe}

Sztuczne ścianki wspinaczkowe w województwie łódzkim cieszą się popularnością zarówno wśród doświadczonych wspinaczy, jak i osób początkujących. Największy okres ich rozwoju przypadała na lata 2005-2009, jednakże wciąż pojawiają się plany oddania do użytku kolejnych obiektów. Większość paneli wspinaczkowych jest umiejscowiona wewnątrz budynków, co umożliwia ich całoroczne użytkowanie. Ściankami wspinaczkowymi charakteryzującymi się najlepszymi parametrami i najbardziej odpowiadającymi pot- 
rzebom użytkowników są obiekty w Łodzi - Stratosfera i AKG. Użytkownikami paneli wspinaczkowych są głównie osoby młode. Cechuje je też stosunkowo wysoki poziom wykształcenia. W większości są to mieszkańcy województwa łódzkiego. Deklarowana przez respondentów duża częstotliwość i mobilność w korzystaniu z paneli może sprzyjać funkcjonowaniu istniejących i powstawaniu nowych obiektów.

\section{BIBLIOGRAFIA}

DURYDIWKA M., 2006, Turystyka aktywna a turystyka kwalifikowana. Dylematy terminologiczne, [w:] A. Świeca, K. Kałmucki (red.), Rozwój turystyki aktywnej na Roztoczu - regionie pogranicza, Kartopol s.c., Lublin.

KIEŁKOWSKA M., 2003, Wielka encyklopedia gór i alpinizmu, t. 1, Wprowadzenie, Stapis, Gliwice.

KUŚKA A., SAS-NOWOSIELSKI K., 1998, Sport wspinaczkowy a wysokogórska turystyka kwalifikowana,

[w:] T. Łobożewicz, R. Kogut (red.), Turystyka aktywna - turystyka kwalifikowana, I ogólnopolska konferencja naukowo-metodyczna, zbiór materiatów pokonferencyjnych, DrukTur, Warszawa.

LIJEWSKI T., MiKUŁOWSKI B., WYRZYKOWSKI J., 2008, Geografia turystyki Polski, PWE, Warszawa. MERSKI J., WARECKA J., 2009, Turystka kwalifikowana, turystyka aktywna, Almamer, Warszawa. WWW.monolitsport.com.pl. 